\title{
The effect of endogenous angiotensin II on alveolar fluid clearance in rats with acute lung injury
}

\author{
Jia Deng $\mathrm{PhD}^{1}$, Dao-xin Wang $\mathrm{MD}^{2}$, Wang Deng $\mathrm{PhD}^{2}$, Chang-yi Li PhD², Jin Tong PhD²
}

\begin{abstract}
J Deng, D Wang, W Deng, C Li, J Tong. The effect of endogenous angiotensin II on alveolar fluid clearance in rats with acute lung injury. Can Respir J 2012;19(5):311-318.
\end{abstract}

BACKGROUND: In acute lung injury (ALI), angiotensin II (Ang II) plays a vital role in the stimulation of pulmonary permeability edema formation through the angiotensin type $1\left(\mathrm{AT}_{1}\right)$ receptor. The effect of Ang II on alveolar fluid clearance (AFC) in ALI remains unknown.

METHODS: Sprague Dawley rats were anesthetized and intratracheally injected with $1 \mathrm{mg} / \mathrm{kg}$ lipopolysaccharide (LPS), while control rats received saline. The $\mathrm{AT}_{1}$ receptor antagonist $\mathrm{ZD} 7155$ was injected intraperitoneally $(10 \mathrm{mg} / \mathrm{kg}) 30 \mathrm{~min}$ before LPS administration. The lungs were isolated for AFC measurement, and alpha-epithelial sodium channel $(\mathrm{ENaC})$ messenger RNA and protein expression were detected by reverse-transcription polymerase chain reaction and Western blot.

RESULTS: LPS-induced ALI caused an increase in Ang II levels in plasma and lung tissue but a decrease in AFC. The time course of Ang II levels paralleled that of AFC. Pretreatment with ZD7155 prevented ALIinduced reduction of AFC. ZD7155 also reversed the ALI-induced reduction of beta-ENaC and gamma-ENaC levels, and further decreased alpha-ENaC levels.

CONCLUSIONS: These findings suggest that endogenous Ang II inhibits $\mathrm{AFC}$ and dysregulates $\mathrm{ENaC}$ expression via $\mathrm{AT}_{1}$ receptors, which contribute to alveolar filling and pulmonary edema in LPS-induced ALI.

Key Words: Acute lung injury; Alveolar fluid clearance; Angiotensin II; Epithelial sodium channel

A cute lung injury (ALI) and acute respiratory distress syndrome, a more severe form of ALI, are both associated with high morbidity and mortality in critically ill patients. However, the exact mechanism underlying ALI is not well defined. Lung inflammation induces the production of various cytokines, such as tumour necrosis factor-alpha and interleukin (IL)-1 beta $(1,2)$, and free radicals (3-5) that mediate lung injury. Meanwhile, pulmonary permeability edema, which can be accompanied by reduced alveolar liquid clearance capacity, is a major complication of ALI (6). Pulmonary permeability edema can be caused by endothelial hyperpermeability and epithelial and endothelial barrier disruption. Recent reports demonstrated that alveolar fluid clearance (AFC) was impaired in a majority of patients with ALI and that maximal AFC was associated with better clinical outcomes (7). Thus, a therapeutic strategy for recovering the balance between alveolar fluid formation and reabsorption may be an effective treatment for ALI.

The renin-angiotensin system (RAS) plays a central role in the control of cardiovascular and renal functions by maintaining sodium balance, extracellular fluid volume and renal and systemic vascular resistance (8). Pulmonary permeability edema is a potentially important target for RAS in the lung. Infusion of angiotensin II (Ang II), which is the main effector of RAS, can produce pulmonary edema. Several mediators, including leukotriene $C_{4}$, prostaglandin $E_{2}$ and vascular permeability factors (9-11), have been implicated in Anginduced vascular permeability changes. Previous studies have suggested that Ang II mediates most of its biological functions through

\section{L'effet de l'angiotensine II endogène sur la clairance du liquide alvéolaire chez des rats ayant une lésion pulmonaire aiguë}

HISTORIQUE : En cas de lésion pulmonaire aiguë (LPA), l'angiotensine II (Ang II) joue un rôle essentiel pour stimuler la formation d'œdème de perméabilité pulmonaire par le récepteur de l'angiotensine de type 1 $\left(\mathrm{AT}_{1}\right)$. On ne connaît pas l'effet de l'Ang II sur la clairance du liquide alvéolaire (CLA) en cas de LPA.

MÉTHODOLOGIE : Les chercheurs ont anesthésié des rats Sprague Dawley et leur ont injecté $1 \mathrm{mg} / \mathrm{kg}$ de lipopolysaccharide (LPS) par voie intratrachéale, tandis que des rats témoins recevaient un soluté physiologique. Ils leur ont injecté un antagoniste des récepteurs de l'AT ZD7155 par voie intrapéritonéale $(10 \mathrm{mg} / \mathrm{kg}) 30$ minutes avant de leur administrer le LPS. Ils ont isolé les poumons pour mesurer la CLA et ont décelé l'ARN messager et l'expression protéique du canal sodium épithélial alpha $(\mathrm{ENaC})$ par la technique de transcription inverse suivie d'une réaction en chaîne de la polymérase et par transfert Western.

RÉSULTATS : Les LPA induites par le LPS provoquaient une augmentation des taux d'Ang II dans le plasma et les tissus pulmonaires, mais une diminution de la CLA. Le cours chronologique des taux d'Ang II était parallèle à celui de la CLA. Un traitement préalable au ZD7155 a permis d'éviter une réduction de la CLA induite par les LPA. Le ZD7155 renversait également la réduction des taux d'ENaC bêta et gamma induits pour la LPA et suscitait une diminution plus prononcée des taux d'ENaC alpha.

CONCLUSIONS : D'après ces observations, l'Ang II endogène inhibe la CLA et dysrégularise l'expression de l'ENaC par les récepteurs de l'AT1, ce qui contribue au remplissage alvéolaire et à l'œdème pulmonaire en cas de LPA induite par le LPS.

angiotensin type $1\left(\mathrm{AT}_{1}\right)$ receptor signalling. In the lung, Ang II also increases vascular permeability via the $\mathrm{AT}_{1}$ receptors (12-14). Moreover, a recent study demonstrated that $\mathrm{AT}_{1}$ receptors moderate the ratio of angiotensin-converting enzyme (ACE)/ACE2 activity and reduced the pulmonary levels of Ang I-VII to halt ALI development (15). These data indicate that pulmonary edema formation in ALI occurs downstream of $\mathrm{AT}_{1}$ receptor activation.

AFC represents alveolar filling and clearance, and is associated with ALI outcome, but the effect of Ang II on AFC in ALI remains unknown. We hypothesized that Ang II inhibits AFC and induces pulmonary edema through $\mathrm{AT}_{1}$ receptors. To test this hypothesis, we examined Ang II levels in plasma and lung tissue, estimated AFC and analyzed lung histopathology in rats with lipopolysaccharide (LPS). induced ALI. To further elucidate the mechanism, we assessed epithelial sodium channel alpha $(\alpha-\mathrm{ENaC})$ expression, and investigated the impact of ZD7155, a specific $\mathrm{AT}_{1}$ receptor antagonist, on AFC changes and $\mathrm{ENaC}$ expression.

Materials

\section{METHODS}

ZD7155, amiloride, sodium pentobarbital and Evans blue were purchased from Sigma (USA).

\section{Animal model}

All protocols involving rats were approved by the Institutional Review Board of Chongqing Medical University (Chongqing, China). Male

${ }^{1}$ Department of Respiratory Medicine; ${ }^{2}$ Department of Medicine, Second Affiliated of Chongqing Medical University, Chongqing, China

Correspondence and reprints: Dr Dao-xin Wang, Department of Respiratory Medicine, Second Affiliated of Chongqing Medical University,

74 Yanjiang Road, Chongqing 400016, China. Telephone 86-23-6369-3094, e-mail wandaoxin1@163.com 
Sprague Dawley rats (220 g to $240 \mathrm{~g}$, Beijing Experimental Animal Center) were anesthetized with an intraperitoneal administration of sodium pentobarbital ( $50 \mathrm{mg} / \mathrm{kg}$ body weight). The experimental rats were intratracheally injected with $1 \mathrm{mg} / \mathrm{kg}$ LPS (Escherichia coli 055:B5, Sigma, USA) dissolved in $0.3 \mathrm{~mL}$ saline, whereas the control rats received saline $(0.3 \mathrm{~mL})$ only. The $\mathrm{AT}_{1}$ receptor antagonist ZD7155 (1 mg/kg, $10 \mathrm{mg} / \mathrm{kg}$ and $20 \mathrm{mg} / \mathrm{kg})$ was intraperitoneally injected $30 \mathrm{~min}$ before LPS administration. The trachea, lungs and hearts were isolated en bloc. The left lungs were separated to measure lung water volume and bronchoalveolar lavage fluid (BALF). The right lungs were prepared to assess AFC.

\section{Measurement of Ang II in plasma and lung tissue \\ Plasma was collected and centrifuged for $15 \mathrm{~min}$ at $1000 \mathrm{~g}$ within $30 \mathrm{~min}$ of collection. The samples were then stored at $\leq-20^{\circ} \mathrm{C}$. The lung tis- sue was frozen and homogenized in ice-cold $1 \mathrm{M}$ trichloroacetic acid and centrifuged at $2500 \mathrm{~g}$ for $10 \mathrm{~min}$ at $4^{\circ} \mathrm{C}$. Ang II levels in plasma and lung tissue were determined using rat angiotensin ELISA kits according to the manufacturer's instructions (R\&D Systems, USA).}

\section{AFC}

AFC was estimated by measuring the progressive increase in the concentration of alveolar Evans blue dye, as previously described (16). Briefly, fluid $(1.5 \mathrm{~mL})$ containing Evans blue-labelled 5\% bovine albumin was instilled into the airway of the right lung, followed by $2 \mathrm{~mL}$ oxygen to deliver the instilled solution into the alveolar spaces. The lungs were then placed in an incubator prewarmed to $37^{\circ} \mathrm{C}$ and inflated to an airway pressure of $7 \mathrm{cmH}_{2} \mathrm{O}$ with $100 \%$ oxygen. After $5 \mathrm{~min}$ (time 0 ) and $65 \mathrm{~min}$ (time $60 \mathrm{~min}$ ), the samples were gently aspirated through a catheter. The change in protein concentration in the $60 \mathrm{~min}$ samples compared with the 0 min samples was used to determine the volume of fluid cleared as follows:

$$
\mathrm{AFC}=\left(\left[\mathrm{V}_{\mathrm{i}}-\mathrm{V}_{\mathrm{f}} / \mathrm{V}_{\mathrm{i}}\right) \times 100 \% \quad \mathrm{~V}_{\mathrm{f}}=\left(\mathrm{V}_{\mathrm{i}} * \mathrm{~EB}_{\mathrm{i}}\right) / \mathrm{EB}_{\mathrm{f}}\right.
$$

$V_{i}$ represents the initial volume, and $V_{f}$ represents the final volume of alveolar fluid. $\mathrm{EB}_{\mathrm{i}}$ and $\mathrm{EB}_{\mathrm{f}}$ represent the concentration of Evans blue dye in the initial and final alveolar fluid solutions, respectively.

\section{Lung water content and BALF}

After the administration of Ang II with or without ZD7155, blood was drawn, and the left lung was removed and dried at $95^{\circ} \mathrm{C}$ for $48 \mathrm{~h}$. Lung water content was estimated by calculating the ratio of the wet lung weight to the dry lung weight $(\mathrm{mg})$ per gram of body weight. Fluid $(2 \mathrm{~mL})$ was instilled into the right lung and extracted carefully. The extracted fluid was centrifuged at $1700 \mathrm{~g}$ for $5 \mathrm{~min}$ at $4^{\circ} \mathrm{C}$ and the cell pellets were resuspended in $1 \mathrm{~mL}$ of $1 \mathrm{M}$ phosphate-buffered saline (PBS). Differential cell counts were assessed on cytological preparations stained with Wright's stain. Cells were counted under light microscopy.

\section{Histological analysis}

The lungs were fixed by immersion in a $10 \%$ formalin solution for one week, from which $3 \mathrm{~mm}$ sections were prepared. These sections were embedded in paraffin, cut into $5 \mu \mathrm{m}$ sections and stained with hematoxylin and eosin. The morphological changes were examined under light microscopy. All photographs were taken at 100x magnification.

\section{Immunocytochemistry}

The lungs were processed for immunological studies as previously described (17). The tissue was dehydrated in graded ethanol and left in xylene overnight. The tissue was then embedded in paraffin and cut into $2 \mu \mathrm{m}$ sections using a rotary microtome. The sections were dewaxed and rehydrated. Endogenous peroxidase activity was blocked with $0.5 \%$ hydrogen peroxide in methanol for $10 \mathrm{~min}$ and the sections were boiled in a target retrieval solution $(1 \mathrm{mmol} / \mathrm{L}$ Tris $[\mathrm{pH} 9.0]$ with $0.5 \mathrm{mmol} / \mathrm{L}$ EGTA) for $10 \mathrm{~min}$. Nonspecific binding was prevented using $50 \mathrm{mmol} / \mathrm{L}$ ammonium chloride in PBS for $30 \mathrm{~min}$ followed by PBS blocking buffer (1\% bovine serum albumin, $0.05 \%$ saponin and $0.2 \%$ gelatin). The sections were incubated with a primary antibody (rabbit anti-ENaC antibody [Abcam, USA]) at $4^{\circ} \mathrm{C}$. The sections were then washed and incubated with horseradish peroxidase-conjugated secondary antibody (goat antirabbit immunoglobulin [Abcam, USA]). After a $1 \mathrm{~h}$ incubation at room temperature, the sections were mounted on coverslips with a hydrophilic mounting medium containing antifade reagent (N-propyl-gallate, P-3101; Sigma Chemical, USA). Light microscopy was performed using a Leica DMRE microscope (Leica Microsystems, Germany). All photographs are at 400x magnification. The number of positive cells in five randomly selected high-power fields from each section was counted and averaged.

\section{Western blot}

Proteins were separated on $10 \%$ sodium dodecyl sulphate polyacrylamide gels and transblotted onto polyvinylidene difluoride membranes. After incubation in a blocking solution $(20 \mathrm{mM}$ Tris- $\mathrm{HCl}[\mathrm{pH}$ 7.5], $0.5 \mathrm{M}$ sodium chloride and 5\% nonfat dried milk) for $1 \mathrm{~h}$, the membrane was incubated with the primary antibody at $4^{\circ} \mathrm{C}$ overnight in a buffer containing $20 \mathrm{mM}$ Tris- $\mathrm{HCl}(\mathrm{pH} 7.5)$, $0.5 \mathrm{M}$ sodium chloride, $0.1 \%$ Tween 20 and $0.2 \%$ nonfat dried milk. The membrane was then incubated with the secondary antibody at room temperature for $1 \mathrm{~h}$. All of the polyclonal antibodies were purchased from Abcam, USA. An electrochemiluminescence kit (Sigma, USA) was used to develop the membranes.

\section{Statististical analysis}

Summary data are shown as the mean and SEM. Student's $t$ tests and Fisher ANOVA tests were used for statistical comparisons between groups. $\mathrm{P}<0.05$ was considered to be statistically significant.

\section{RESULTS}

Ang II levels in plasma and lung tissue

After intratracheal injection of LPS $(1 \mathrm{mg} / \mathrm{kg})$ for different time courses ( $2 \mathrm{~h}, 4 \mathrm{~h}$ and $6 \mathrm{~h}$ ), Ang II levels in the plasma and lung tissue were determined using ELISA. In plasma (Figure 1, upper panel), Ang II levels increased in the rats with ALI at $2 \mathrm{~h}, 4 \mathrm{~h}$ and $6 \mathrm{~h}$ when compared with the control rats (control $1.03 \pm 0.25 \mu \mathrm{g} / \mathrm{L}$; ALI at $2 \mathrm{~h}$ $2.53 \pm 0.4 \mu \mathrm{g} / \mathrm{L} ;$ ALI at $4 \mathrm{~h} 3.78 \pm 1.15 \mu \mathrm{g} / \mathrm{L}$, ALI at $6 \mathrm{~h} 4.91 \pm 1.1 \mu \mathrm{g} / \mathrm{L})$. In lung tissue (Figure 1, lower panel), the concentrations of Ang II in the rats with ALI for $2 \mathrm{~h}, 4 \mathrm{~h}$ and $6 \mathrm{~h}$ were also higher than in the control group and increased in a time-dependent manner (control $78.34 \pm 17.7 \mathrm{ng} / \mathrm{g}$; ALI at $2 \mathrm{~h} 190.2 \pm 38.23 \mathrm{ng} / \mathrm{g}$, ALI at $4 \mathrm{~h}$ $305 \pm 72.99 \mathrm{ng} / \mathrm{g}, \mathrm{ALI}$ at $6 \mathrm{~h} 580.4 \pm 129.16 \mathrm{ng} / \mathrm{g}$ ).

\section{Effect of $\mathrm{AT}_{1}$ blockade on lung water volume}

Lung water content was examined at different time points after intratracheal injection of LPS (1 mg/kg) (Figure 2). Lung water volume increased in the rats with ALI compared with that in the controls (control $3.94 \pm 1.11 \mathrm{~g} / \mathrm{g}$; ALI at $2 \mathrm{~h} 5.55 \pm 0.64 \mathrm{~g} / \mathrm{g}$, ALI at $4 \mathrm{~h}$ $5.76 \pm 0.89 \mathrm{~g} / \mathrm{g}$, ALI at $6 \mathrm{~h} 8.29 \pm 1.04 \mathrm{~g} / \mathrm{g}$ ). The lung water volume in the $1 \mathrm{mg} / \mathrm{kg}$ ZD7155 pretreatment group was not significantly different from that of the ALI at $6 \mathrm{~h}$ group $(P>0.05)$; however, the $10 \mathrm{mg} / \mathrm{kg}$ ZD7155 pretreatment decreased lung water volume $(6.94 \pm 0.829 \mathrm{~g} / \mathrm{g})$. Pretreatment with $20 \mathrm{mg} / \mathrm{kg}$ ZD7155 did not have an additional effect on lung water volume compared with a pretreatment of $10 \mathrm{mg} / \mathrm{kg}$ ZD7155 (P>0.05).

\section{Effect of $\mathrm{AT}_{1}$ blockade on AFC}

AFC was measured $1 \mathrm{~h}$ after fluid instillation in the rats with ALI (Figure 3). Fluid clearance was approximately $13.6 \%$ in the control group. However, AFC decreased by approximately $26.5 \%, 45.6 \%$ and $67.6 \%$ in rats with ALI for $2 \mathrm{~h}, 4 \mathrm{~h}$ and $6 \mathrm{~h}$, respectively.

To further elucidate the mechanism of AFC reduction in rats with ALI, amiloride $(100 \mu \mathrm{M})$ and ZD7155 $\left(10^{-6} \mathrm{M}\right)$ were added to the instillate for fluid clearance measurement. The addition of amiloride to the instillate decreased fluid clearance by $85.3 \%$ compared with the control group (13.6\%). AFC decreased by $67.6 \%$ in the rats with ALI for $6 \mathrm{~h}$. However, there was no significant effect in the rats with ALI 


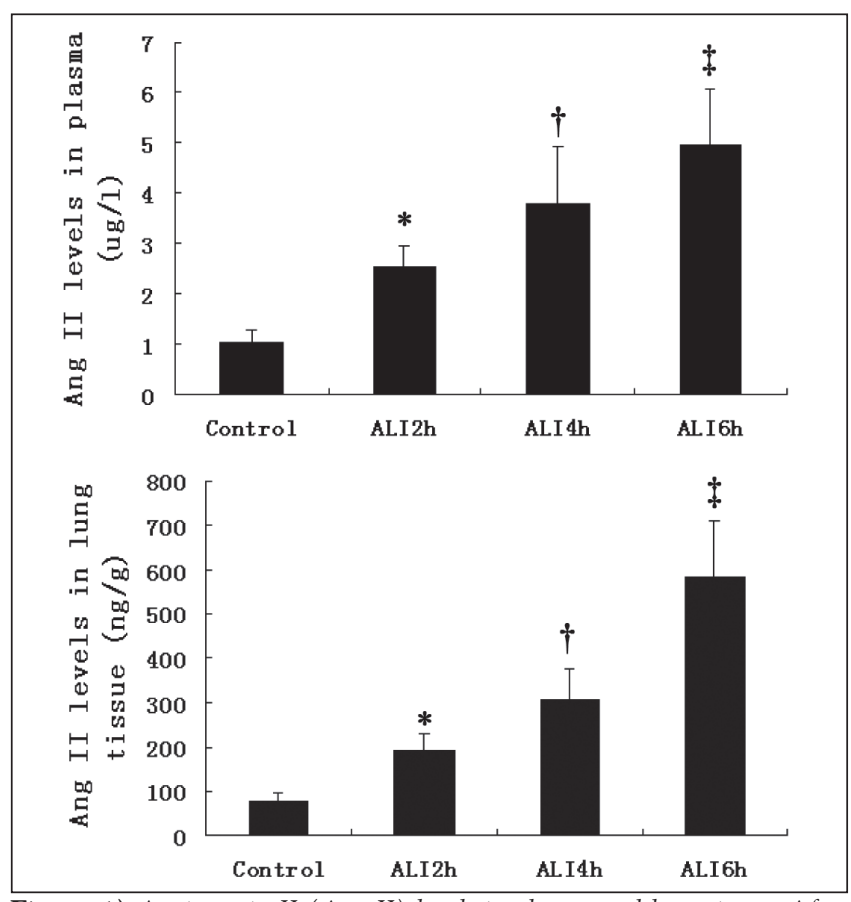

Figure 1) Angiotensin II (Ang II) levels in plasma and lung tissue. After administration of lipopolysaccharide (1 mg/kg), Ang II levels in the plasma and lung tissue were determined using ELISA ( $n=5$ per group). Data presented as mean \pm SEM. $* P<0.05$ versus control, ${ }^{\dagger} P<0.05$ versus acute lung injury (ALI) at $2 h ; \stackrel{+}{+}<0.05$ versus $A L I$ at $4 h$

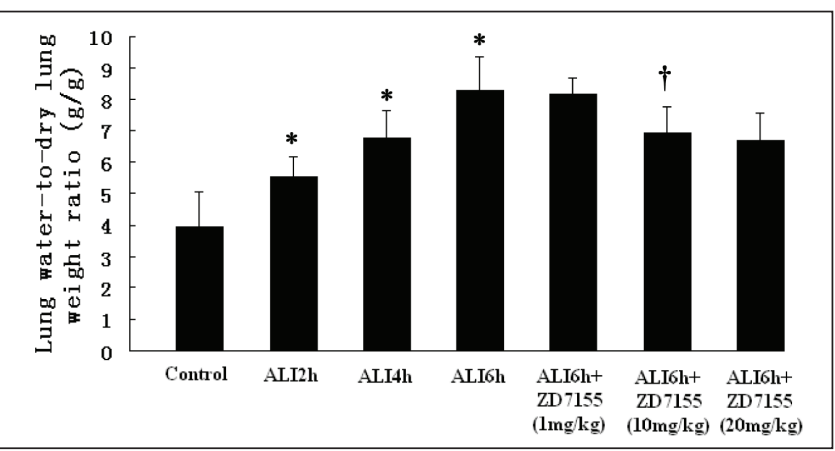

Figure 2) Lung water volume in rats with lipopolysaccharide (LPS)induced acute lung injury (ALI). After administration of LPS (1 mg/kg) with or without ZD7155 (1 mg/ $/ \mathrm{kg}, 10 \mathrm{mg} / \mathrm{kg}$ or $20 \mathrm{mg} / \mathrm{kg})$, lung water volume was estimated by calculating the ratio of the wet lung weight to the dry lung weight $(\mathrm{mg})$ per gram of body weight ( $n=5$ per group). Data presented as mean \pm SEM. $* P<0.01$ versus control; ${ }^{\dagger} P<0.05$ versus ALI at $6 h$

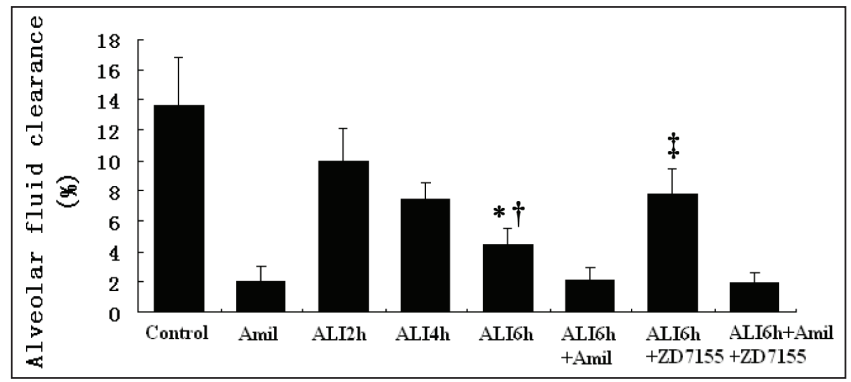

Figure 3) Effect of angiotensin type 1 receptor antagonist on alveolar fluid clearance in rats with acute lung injury (ALI). Alveolar fluid clearance was measured $1 \mathrm{~h}$ after fluid instillation in the rats with ALI for $2 \mathrm{~h}, 4 \mathrm{~h}$ and $6 \mathrm{~h}$. Amiloride (Amil) $(100 \mu \mathrm{M})$ and ZD7155 $\left(10^{-6} \mathrm{M}\right)$ were added to the instillate as indicated ( $n=5$ per group). Data presented as mean \pm SEM. $* P<0.05$ versus ALI at $6 h+A$ mil; ${ }^{\dagger} P<0.01$ versus ALI at $6 h+2 D 7155$; $\ddagger P<0.01$ versus ALI at $6 h+$ Amil + ZD7155

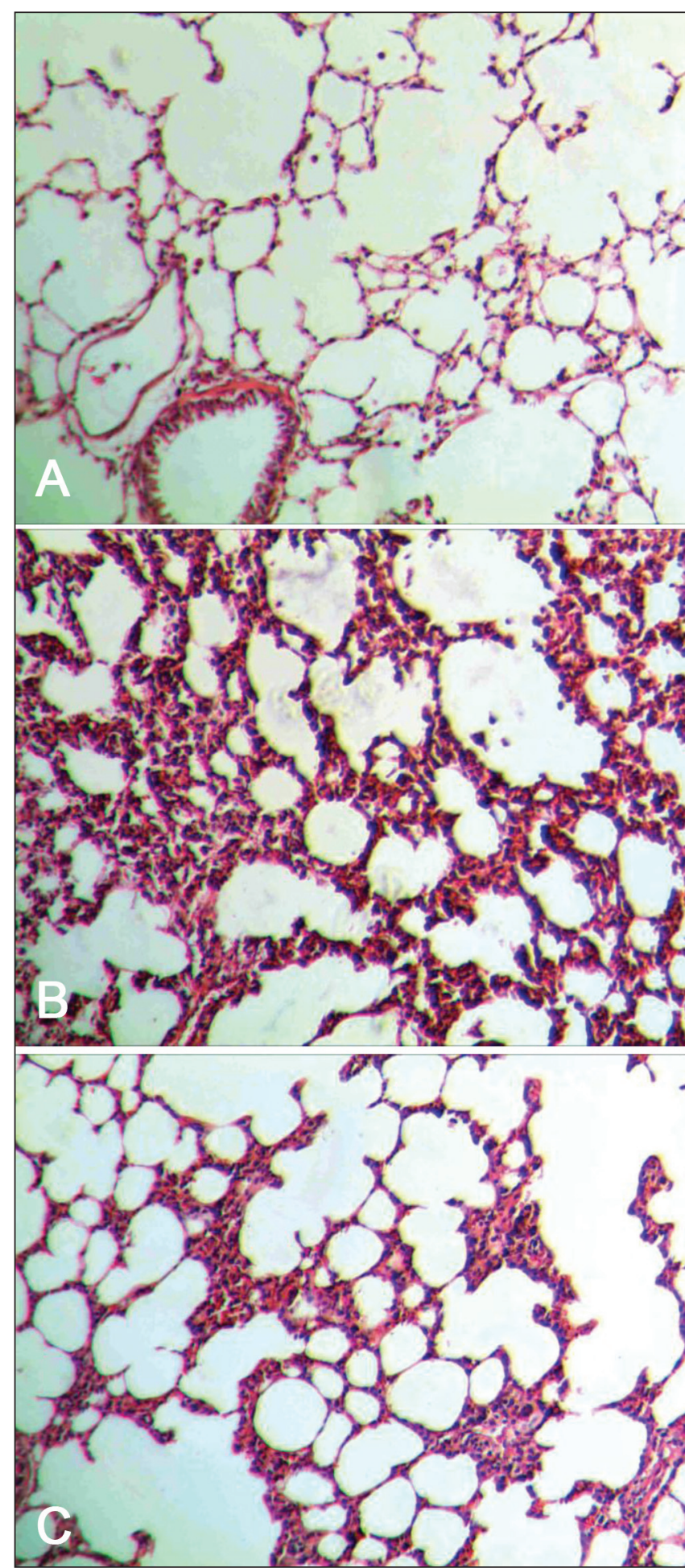

Figure 4) Histological analysis of rat lung (original magnification $\times 100$ ). Rats were intratracheally injected with lipopolysaccharide $(1 \mathrm{mg} / \mathrm{kg})$ or saline $(0.3 \mathrm{~mL}$ saline $)$. ZD7155 (10 mg/kg) was injected intraperitoneally $30 \mathrm{~min}$ before lipopolysaccharide administration. Representative specimens from the control (A), acute lung injury (ALI) at $6 \mathrm{~h}$ (B) and ALI at $6 \mathrm{~h}$ with ZD7155 (C) groups are shown. Interstitial edema and inflammatory cell infiltration were seen in the ALI at 6 hroup but were attenuated in the ALI at 6 h with ZD7155 group

for $6 \mathrm{~h}$ when amiloride was added to the instillate $(\mathrm{P}>0.05)$. The addition of the $\mathrm{AT}_{1}$ receptor antagonist ZD7155 prevented the ALIinduced inhibition of AFC $(7.8 \pm 1.61 \%$ versus $4.4 \pm 1.14 \%)$. The 

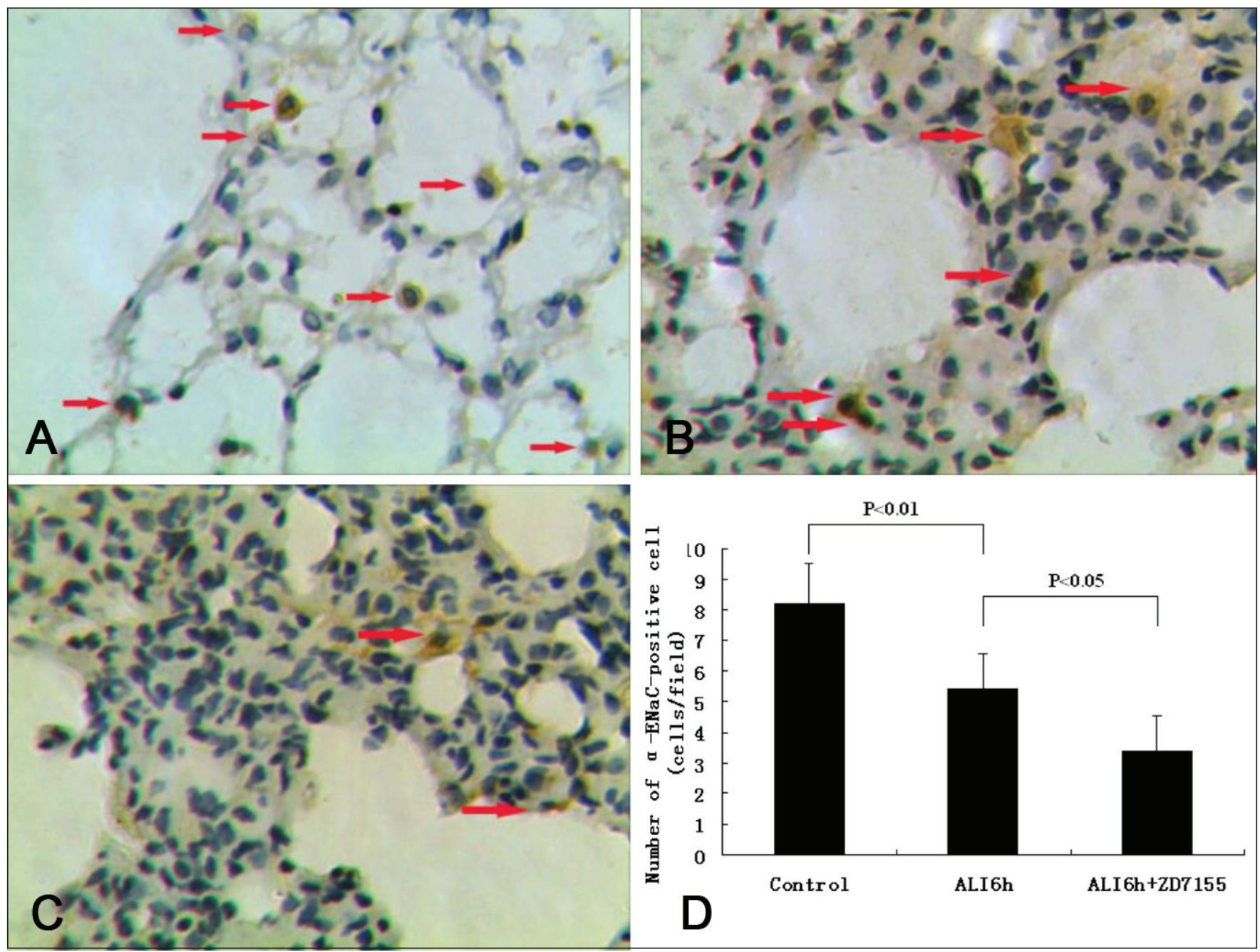

Figure 5) Changes in epithelial sodium channel-alpha $(\alpha-E N a C)$ protein expression in lung tissue specimens. Immunohistochemical analysis was used to detect $\alpha-E N a C$ in the lung tissue. Representative specimens from control (A), acute lung injury (ALI) at $6 \mathrm{~h}(\mathrm{~B})$ and ALI at $6 \mathrm{~h}$ plus ZD7155 (C) groups are shown. Arrows indicate $\alpha$-ENaC-positive cells, which were counted in five randomly selected high-power fields from each section and averaged (D). Figures $5 \mathrm{~A}$, 5B and $5 \mathrm{C}$ are at $400 \times$ magnification. The number of $\alpha-E N a C$-positive cells decreased in the ALI at 6 h group and further decreased in the ZD7155-treated group

addition of both amiloride and ZD7155 in the instillate in rats with ALI for $6 \mathrm{~h}$ showed no further effect versus the addition of amiloride alone in the rats with ALI $(2.1 \pm 0.78 \%$ versus $1.9 \pm 0.74 \%[\mathrm{P}>0.05])$.

\section{Histological alteration in lung tissue}

Lung tissue specimens were obtained $6 \mathrm{~h}$ after intratracheal LPS injection with or without ZD7155 pretreatment. There was no histological alteration in the control group (Figure 4A). Interstitial edema and inflammatory cell infiltration were observed in the rats with ALI (Figure 4B). However, ZD7155 ameliorated the interstitial edema and inflammatory cell infiltration in the lung (Figure 4C). The histological changes observed under the microscope and in the BALF analysis (not shown) were consistent with the lung water volume described above (Figure 2).

Immunohistochemical analysis of the lung

Immunohistochemical analysis revealed that the number of cells expressing $\alpha$-ENaC (Figure 5B), $\beta$-ENaC (Figure 6B) and $\gamma$-ENaC (Figure 7B) all decreased in the rats with ALI for 6 h. ZD7155 pretreatment increased the number of cells expressing $\beta$-ENaC (Figure $6 \mathrm{C}$ ) and $\gamma-\mathrm{ENaC}$ (Figure $7 \mathrm{C}$ ) but further reduced the number of $\alpha-\mathrm{ENaC}$ positive cells (Figure $5 \mathrm{C}$ ). The immunohistochemical changes were consistent with the Western blot analyses (Figure 8).

Effect of $\mathrm{AT}_{1}$ blockade on $\mathrm{ENaC}$ protein expression

$\mathrm{ENaC}$ protein expression was examined in the rats with ALI with or without ZD7155 pretreatment (Figure 8). Intratracheal LPS injection resulted in significant inhibition of $\alpha-\mathrm{ENaC}(0.22 \pm 0.03$ versus control $0.38 \pm 0.042), \beta-\mathrm{ENaC}(0.17 \pm 0.041$ versus control $0.368 \pm 0.063)$ and $\gamma$-ENaC $(0.37 \pm 0.055$ versus control $0.67 \pm 0.073)$ expression. In contrast, ZD7155 pretreatment increased the protein expression of $\beta$-ENaC $(0.26 \pm 0.043$ versus ALI at $6 \mathrm{~h})$ and $\gamma$-ENaC $(0.47 \pm 0.051$ versus ALI at $6 \mathrm{~h})$. However, the $\alpha-\mathrm{ENaC}$ protein expression further decreased in the ZD7155 pretreatment group $(0.158 \pm 0.039$ versus ALI at $6 \mathrm{~h})$.

\section{DISCUSSION}

We previously studied the effects of exogenous Ang II on AFC in Sprague-Dawley rats (18). However, the pathophysiological process in rats with ALI is significantly more complicated. Therefore, we studied the effects of endogenous Ang II on AFC and $\mathrm{ENaC}$ expression and made three key observations. First, Ang II levels in plasma and lung tissue increased in a time-dependent manner in the rats with ALI. Second, AFC decreased in the rats with ALI, but pretreatment with the $\mathrm{AT}_{1}$ receptor antagonist prevented the ALI-induced reduction of AFC. Third, the $\mathrm{AT}_{1}$ receptor antagonist further decreased the levels of $\alpha-\mathrm{ENaC}$ but reversed the ALI-induced reduction of $\beta$-ENaC and $\gamma$-ENaC levels. These observations suggested that LPS-induced ALI enhanced the release of Ang II, which exerted its effects through AT $_{1}$ receptor activation in the lung and resulted in a decrease in AFC and altered $\mathrm{ENaC}$ expression. 

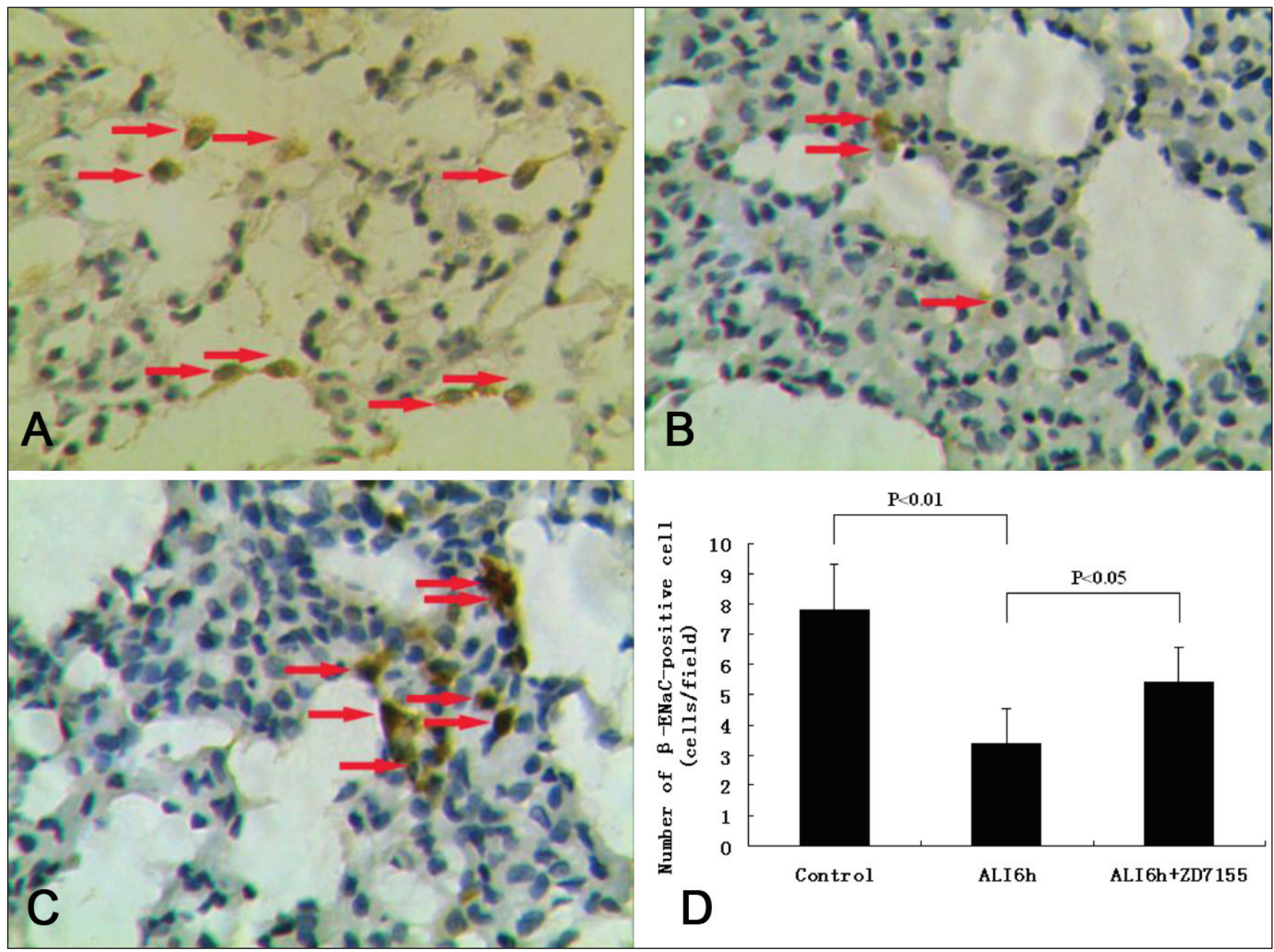

Figure 6) Changes in epithelial sodium channel-beta ( $\beta$-ENaC) protein expression in lung tissue specimens. Immunohistochemical analysis was used to detect $\beta-E N a C$ in lung tissue. The representative specimens from control (A), acute lung injury (ALI) at $6 \mathrm{~h}(\mathrm{~B})$ and ALI at 6 h plus ZD7155 (C) groups are shown. Arrows indicate $\beta-E N a C$-positive cells, which were counted in five randomly selected high-power fields from each section and averaged (D). Figures $6 \mathrm{~A}, 6 \mathrm{~B}$ and $6 \mathrm{C}$ are at $400 \times$ magnification. The number of $\alpha-E N a \mathrm{C}$-positive cells decreased in the ALI at 6 h group but increased in the ZD7155-treated group

Mounting evidence from renal and gastrointestinal studies demonstrate that Ang II has direct effects on the renal tubule (19-21), colonic epithelium (22) and vascular smooth muscle cells (23) in regulating sodium and water reabsorption, which suggests that Ang II plays a pivotal role in the maintenance of body fluid volume homeostasis and extracellular fluid volume contraction. In the present study, pretreatment with an $\mathrm{AT}_{1}$ receptor antagonist significantly decreased the ALI-induced lung water volume. This observation is consistent with our previous study and demonstrates that Ang II induces lung water volume aggregation through $\mathrm{AT}_{1}$ receptor activation.

To further elucidate the mechanism of pulmonary edema formation, we examined AFC, which is used to assess the balance between alveolar fluid formation and reabsorption. Our results showed that AFC decreased significantly in rats with ALI. Several mechanisms are responsible for decreased AFC; however, an Ang II-dependent mechanism has not been previously examined. In the present study, the mean levels of Ang II in the plasma and lung tissue progressively increased with prolonged ALI treatment time. The time course of the Ang II levels in the plasma and lung tissue paralleled that of AFC. Moreover, $\mathrm{AT}_{1}$ receptor blockade prevented the ALI-induced inhibition of AFC. These results indicate that endogenous Ang II plays a role in decreased AFC. In our study, the addition of amiloride eliminated the effects of the $\mathrm{AT}_{1}$ receptor antagonist on $\mathrm{AFC}$, which implied that the inhibitory effect induced by endogenous Ang II is amiloride sensitive. Amiloride is a specific sodium channel blocker and exerts its specific inhibitory effect on transepithelial sodium transport by $\mathrm{ENaC}$ (24). In the rectum, Ang II decreased the amiloride-sensitive rectal transepithelial potential difference and exerted a negative effect on ENaC activity (25).

Because our results indicated that the effect of Ang II on AFC is amiloride sensitive, we hypothesized that endogenous Ang II plays a role in modulating the expression of amiloride-sensitive $\mathrm{ENaC}$. The protein expression levels of the three $\mathrm{ENaC}$ subunits decreased in the rats with ALI. The $\mathrm{AT}_{1}$ receptor antagonist prevented the inhibitory effects on $\beta$-ENaC and $\gamma$-ENaC expression but further decreased $\alpha-\mathrm{ENaC}$ expression. Thus, one may postulate that endogenous Ang II in rats with ALI downregulates $\beta$-ENaC and $\gamma$-ENaC but upregulates $\alpha-\mathrm{ENaC}$ protein expression. The reason why $\alpha-\mathrm{ENaC}$ expression in the rats with ALI remained lower than that in the control group despite the upregulation effect by Ang II may be explained by the possibility that the mechanisms and molecules involved in acute lung injury pathophysiology are much more complicated, and there may exist many other factors such as the inflammatory responses and oxidative stress that influence $\mathrm{ENaC}$ expression. ENaC expression dysregulation by Ang II was also observed in previous studies. Evidence from the kidney $(26,27)$ and vascular smooth muscle cells (23) suggests noncoordinated regulation of $\alpha-\mathrm{ENaC}$ versus $\beta$-ENaC and $\gamma-\mathrm{ENaC}$ levels. These results suggest that $\alpha-\mathrm{ENaC}$ regulation by 

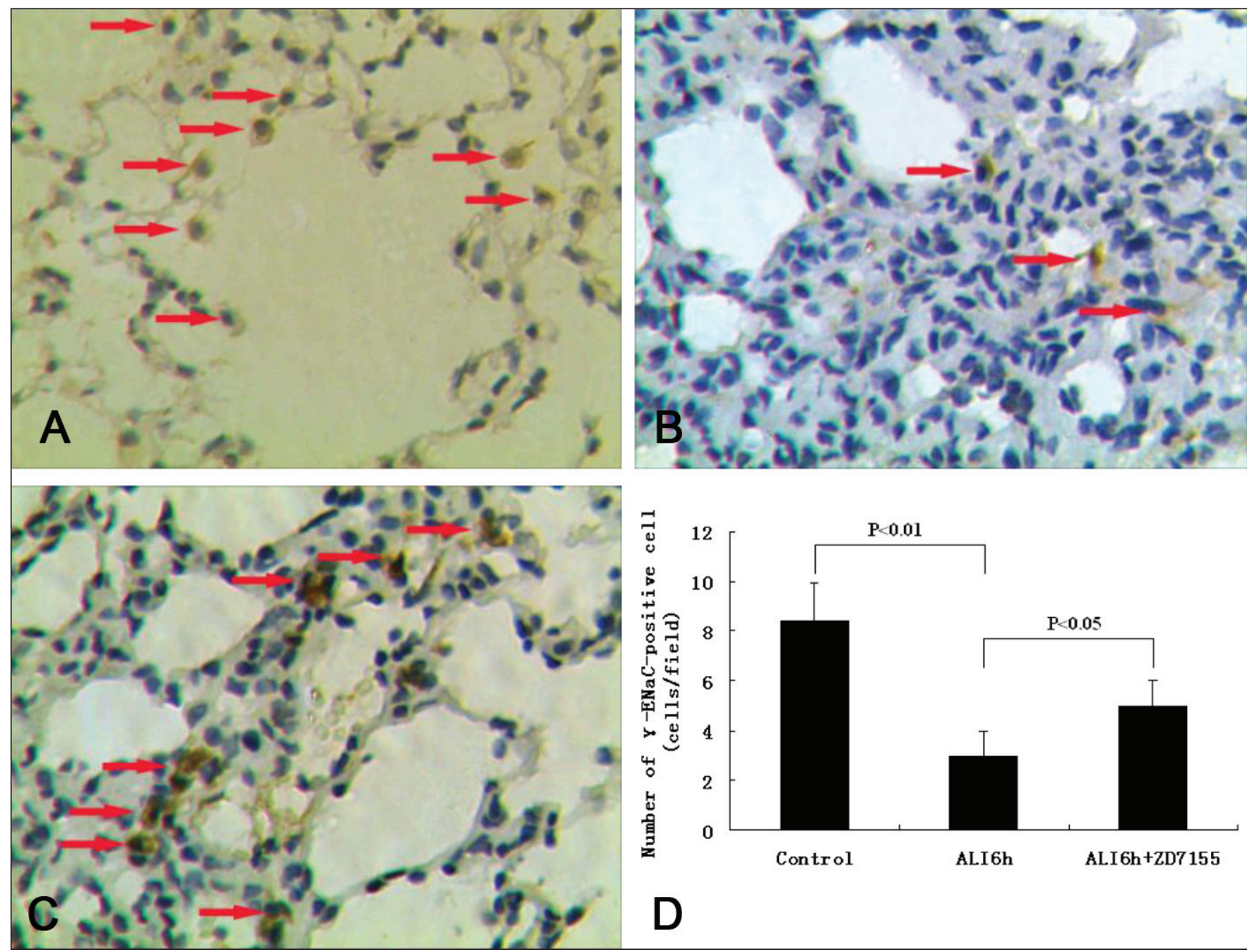

Figure 7) Changes in epitherlial sodium channel-gamma $(\gamma-E N a C)$ protein expression in lung tissue specimens. Immunohistochemical analysis was used to detect $\gamma-\mathrm{ENaC}$ in the lung tissue. Representative specimens from control (A), acute lung injury (ALI) at $6 \mathrm{~h}(\mathrm{~B})$ and $\mathrm{ALI}$ at $6 \mathrm{~h}$ plus $\mathrm{ZD} 7155(\mathrm{C})$ groups are shown. Arrows indicate $\gamma$-ENaC-positive cells, which were counted in five randomly selected high-power fields from each section and averaged (D). All photographs are at 400x magnification. The number of $\alpha-E N a C$-positive cells decreased in the ALI at 6 hroup but increased in the ZD7155-treated group

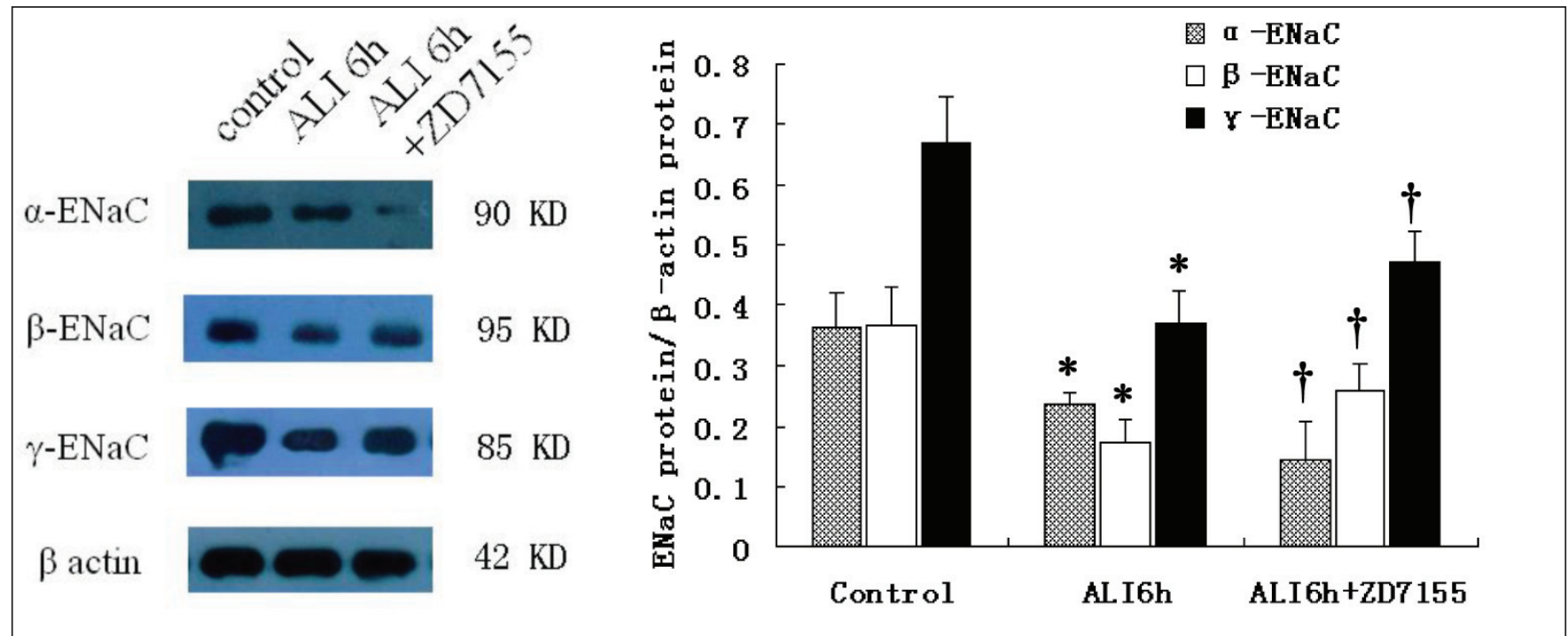

Figure 8) Epithelial sodium channel (ENaC) protein expression in rats. The protein expression levels of $\alpha$-, $\beta$ - and $\gamma$-ENaC were determined by Western blot (left panel) in the rats with lipopolysaccharide-induced acute lung injury (ALI) (1 mg/kg) for $6 \mathrm{~h}$. ZD7155 (10 mg/kg) was injected intraperitoneally $30 \mathrm{~min}$ before lipopolysaccharide administration. Data (mean \pm SEM) are shown in the right panel. $* P<0.01$ versus control; ${ }^{\dagger} P<0.05$ versus ALI at $6 \mathrm{~h}$ 
Ang II is independent of $\beta$ - and $\gamma-\mathrm{ENaC}$ regulation. There are two different forms of ENaC: the highly selective cation (HSC) channels and the nonselective cation channels $(28,29)$. The HSC channels are typical ENaCs composed of the three subunits $\alpha, \beta$ and $\gamma$, whereas nonselective cation channelschannels are only composed of $\alpha$-ENaC. Recent data from genetically engineered mice indicated that a reduced number of HSC channels impair total and ENaC-mediated AFC (30). Therefore, the Ang II-induced $\mathrm{ENaC}$ in our study actually led to a change in the proportion of HSC channels, which inhibited the alveolar fluid reabsorption of amiloride-sensitive $\mathrm{ENaC}$. In our previous study, we reported that the downregulation of cyclic AMP levels by the activation of Ang II in the lung decreases AFC and influences the trafficking of $\mathrm{ENaC}$ subunits to the cell surface (18). Intracellular cyclic AMP concentration may be an important factor that contributes to the regulation of $\mathrm{AFC}$ and $\mathrm{ENaC}$ expression.

Previous data obtained from the lung (31), blood vessel endothelium (32) and artery wall (33) indicate that Ang II, through $\mathrm{AT}_{1}$ receptor activation, plays a primary role in the inflammatory response. Our results are consistent with studies in which the $\mathrm{AT}_{1}$ receptor antagonist prevented ALI-induced interstitial edema and inflammatory cell infiltration according to both the BALF and histological examination. Hence, studies that assess the effects of the inflammatory response on $\mathrm{AFC}$ and $\mathrm{ENaC}$ expression are needed. In our study, AFC was not significantly different among the amiloride group, the ALI+amiloride group and the ALI+amiloride+ZD7155 pretreatment group. This result suggests that Ang II affects amiloride-sensitive $\mathrm{ENaC}$ and that this is the main pathway responsible for altered AFC in our animal model. Meanwhile, an inflammatory response may lead to reduced $\mathrm{ENaC}$ expression in vivo $(34,35)$ and in vitro $(36)$, whereas the noncoordinated regulation of $\alpha-\mathrm{ENaC}$ versus $\beta$-ENaC and $\gamma-\mathrm{ENaC}$ levels downstream of the inflammatory response has not been previously observed. Therefore, it is unlikely that the inflammatory response played a role in $\mathrm{AFC}$ and dysregulated $\mathrm{ENaC}$ expression in the present study.

The present study has several limitations. First, aside from alveolar $\mathrm{ENaC}$, there are other ENaCs in the lung, such as bronchial epithelial $\mathrm{ENaCs}$. Therefore, a better approach would be to examine the $\mathrm{ENaC}$ levels in the apical membrane. Second, we did not assess ENaC messenger RNA expression. Third, we investigated the acute effects of Ang II within 6 h; however, chronic effects remain to be elucidated.

\section{CONCLUSION}

We showed that Ang II levels in plasma and lung tissue are increased in rats with ALI and that an $\mathrm{AT}_{1}$ receptor antagonist prevented the ALI-induced reduction of $\mathrm{AFC}$ and modulated $\mathrm{ENaC}$ expression in rats. These results suggest that endogenous Ang II inhibits AFC via $\mathrm{AT}_{1}$ receptors in rats with ALI.

ACKNOWLEDGEMENTS: The authors thank the members of the Wang laboratory for their invaluable advice and discussions. This study was supported by a grant from the National Natural Science Foundation of China (Grant No. 30971301).

AUTHOR CONTRIBUTIONS: Conception and design: Jia Deng and Dao-xin Wang. Financial support: Dan-xin Wang. Collection and assembly of data: Jia Deng, Wang Deng. Data analysis and interpretation: Jia Deng, Wang Deng, Chang-yi Li, Jin Tong and Dao-xin Wang. Manuscript writing: Jia Deng and Dao-xin Wang.

\section{REFERENCES}

1. Worthen GS, Haslett C, Rees AJ, Gumbay RS, Henson JE, Henson PM. Neutrophil-mediated pulmonary vascular injury. Synergistic effect of trace amounts of lipopolysaccharide and neutrophil stimuli on vascular permeability and neutrophil sequestration in the lung. Am Rev Respir Dis 1987;136:19-28.

2. Wang F, Xia ZF, Chen XL, Jia YT, Wang YJ, Ma B. Angiotensin II type-1 receptor antagonist attenuates LPS-induced acute lung injury. Cytokine 2009;48:246-53.

3. Hassoun PM, Yu FS, Cote CG, et al. Upregulation of xanthine oxidase by lipopolysaccharide, interleukin-1, and hypoxia. Role in acute lung injury. Am J Respir Crit Care Med 1998;158:299-305.

4. Sato K, Suga M, Akaike T, et al. Therapeutic effect of erythromycin on influenza virus-induced lung injury in mice. Am J Respir Crit Care Med 1998;157:853-7.

5. Kelleher ZT, Potts EN, Brahmajothi MV, et al. NOS2 regulation of LPS-induced airway inflammation via S-nitrosylation of NF-\{kappa\}B p65. Am J Physiol Lung Cell Mol Physiol 2011;301:327-33.

6. Lucas R, Verin AD, Black SM, Catravas JD. Regulators of endothelial and epithelial barrier integrity and function in acute lung injury. Biochem Pharmacol 2009;77:1763-72.

7. Ware LB, Matthay MA. Alveolar fluid clearance is impaired in the majority of patients with acute lung injury and the acute respiratory distress syndrome. Am J Respir Crit Care Med 2001;163:1376-83.

8. Beutler KT, Masilamani S, Turban S, et al. Long-term regulation of ENaC expression in kidney by angiotensin II. Hypertension 2003;41:1143-50.

9. Imai Y, Kuba K, Penninger JM. The discovery of angiotensinconverting enzyme 2 and its role in acute lung injury in mice. Exp Physiol 2008;93:543-8.

10. Suzuki Y, Ruiz-Ortega M, Lorenzo O, Ruperez M, Esteban V, Egido J. Inflammation and angiotensin II. Int J Biochem Cell Biol 2003;35:881-900.

11. Abdi R, Dong VM, Lee CJ, Ntoso KA. Angiotensin II receptor blocker-associated angioedema: On the heels of ACE inhibitor angioedema. Pharmacotherapy 2002;22:1173-5.

12. Kiely DG, Cargill RI, Wheeldon NM, Coutie WJ, Lipworth BJ. Haemodynamic and endocrine effects of type 1 angiotensin II receptor blockade in patients with hypoxaemic cor pulmonale. Cardiovasc Res 1997;33:201-8.
13. Xu ZH, Shimakura K, Yamamoto T, Wang LM, Mineshita S. Pulmonary edema induced by angiotensin I in rats. Jpn J Pharmacol 1998;76:51-6.

14. Yamamoto T, Wang L, Shimakura K, Sanaka M, Koike Y, Mineshita S. Angiotensin II-induced pulmonary edema in a rabbit model. Jpn J Pharmacol 1997;73:33-40.

15. Wösten-van Asperen RM, Lutter R, Specht PA, et al. Acute respiratory distress syndrome leads to reduced ratio of ACE/ACE2 activities and is prevented by angiotensin-(1-7) or an angiotensin II receptor antagonist. J Pathol 2011;225(4):618-627.

16. Sakuma T, Zhao Y, Sugita M, et al. Malnutrition impairs alveolar fluid clearance in rat lungs. Am J Physiol Lung Cell Mol Physiol 2004;286:1268-74.

17. Hager H, Kwon TH, Vinnikova AK, et al. Immunocytochemical and immunoelectron microscopic localization of alpha-, beta-, and gamma-ENaC in rat kidney. Am J Physiol Renal Physiol 2001;280:1093-106

18. Deng J, Wang DX, Deng W, Li CY, Tong J, Ma H. Regulation of alveolar fluid clearance and $\mathrm{ENaC}$ expression in lung by exogenous angiotensin II. Respir Physiol Neurobiol 2011 (Epub ahead of print).

19. Tanemoto M, Uchida S. Angiotensin II-induced phosphorylation of the sodium chloride cotransporter. Kidney Int 2011;79:1381-2.

20. Sangalli F, Carrara F, Gaspari F, et al. Effect of ACE inhibition on glomerular permselectivity and tubular albumin concentration in the renal ablation model. Am J Physiol Renal Physiol 2011;300:1291-300.

21. Li C, Wang W, Rivard CJ, Lanaspa MA, Summer S, Schrier RW. Molecular mechanisms of angiotensin II stimulation on aquaporin-2 expression and trafficking. Am J Physiol Renal Physiol 2011;300:1255-61.

22. Hatch M, Freel RW. Increased colonic sodium absorption in rats with chronic renal failure is partially mediated by $\mathrm{AT}_{1}$ receptor agonism. Am J Physiol Gastrointest Liver Physiol 2008;295:348-56.

23. Jernigan NL, Speed J, LaMarca B, Granger JP, Drummond HA. Angiotensin II regulation of renal vascular $\mathrm{ENaC}$ proteins. Am J Hypertens 2009;22:593-7.

24. Benos DJ, Saccomani G, Sariban-Sohraby S. The epithelial sodium channel. Subunit number and location of the amiloride binding site. J Biol Chem 1987;262:10613-8. 
25. Wang Q, Horisberger JD, Maillard M, Brunner HR, Rossier BC, Burnier M. Salt-and angiotensin II-dependent variations in amiloride-sensitive rectal potential difference in mice. Expression and activity of NKCC2, NCC, and ENaC in the obese Zucker rat. Am J Physiol Clin Exp Pharmacol Physiol 2000;27:60-6.

26. Madala Halagappa VK, Tiwari S, Riazi S, Hu X, Ecelbarger CM. Chronic candesartan alters expression and activity of NKCC2, $\mathrm{NCC}$, and $\mathrm{ENaC}$ in the obese Zucker rat. Am J Physiol Renal Physiol 2008;294:1222-31.

27. Lütken SC, Kim SW, Jonassen T, et al. Changes of renal AQP2, $\mathrm{ENaC}$, and $\mathrm{NHE} 3$ in experimentally induced heart failure: Response to angiotensin II AT1 receptor blockade. Am J Physiol Renal Physiol 2009;297:1678-88.

28. Johnson MD, Bao HF, Helms MN, et al. Functional ion channels in pulmonary alveolar type I cells support a role for type I cells in lung ion transport. Proc Natl Acad Sci USA 2006;103:4964-9.

29. Jain L, Chen XJ, Ramosevac S, Brown LA, Eaton DC. Expression of highly selective sodium channels in alveolar type II cells is determined by culture conditions. Am J Physiol Lung Cell Mol Physiol 2001;280:646-58.

30. Randrianarison N, Clerici C, Ferreira C, et al. Low expression of the beta-ENaC subunit impairs lung fluid clearance in the mouse. Am J Physiol Lung Cell Mol Physiol 2008;294:409-16.
31. Nakada TA, Russell JA, Boyd JH, et al. Association of angiotensin II type 1 receptor-associated protein gene polymorphism with increased mortality in septic shock. Crit Care Med 2011;39:1641-8.

32. Medzhitov R, Horng T. Transcriptional control of the inflammatory response. Nat Rev Immunol 2009;9:692-703.

33. Rateri DL, Moorleghen JJ, Balakrishnan A, et al. Endothelial cell-specific deficiency of Ang II type 1a receptors attenuates Ang II-induced ascending aortic aneurysms in LDL receptor -1 mice. Circ Res 2011;108:574-81.

34. Yamagata T, Yamagata Y, Nishimoto T, et al. The regulation of amiloride-sensitive epithelial sodium channels by tumor necrosis factor-alpha in injured lungs and alveolar type II cells. Respir Physiol Neurobiol 2009;166:16-23.

35. Roux J, Kawakatsu H, Gartland B, et al. Interleukin-1beta decreases expression of the epithelial sodium channel alphasubunit in alveolar epithelial cells via a p38 MAPK-dependent signaling pathway. J Biol Chem 2005;280:18579-89.

36. Boncoeur E, Tardif V, Tessier MC, et al. Modulation of epithelial sodium channel activity by lipopolysaccharide in alveolar type II cells: involvement of purinergic signaling. Am J Physiol Lung Cell Mol Physiol 2010;298:417-26. 


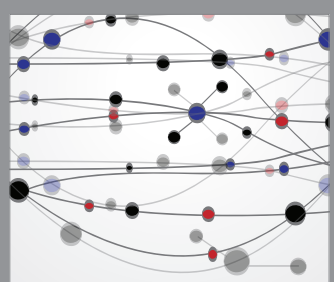

The Scientific World Journal
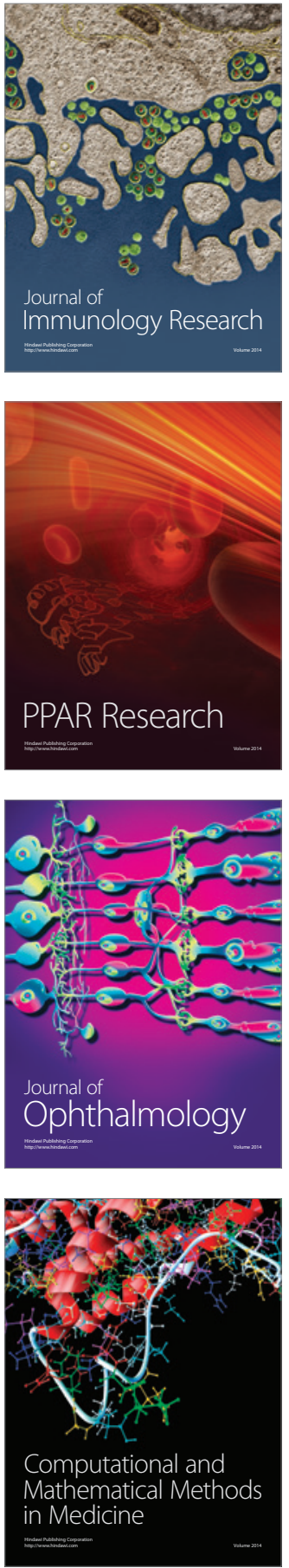

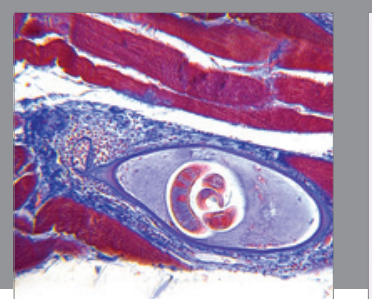

Gastroenterology Research and Practice

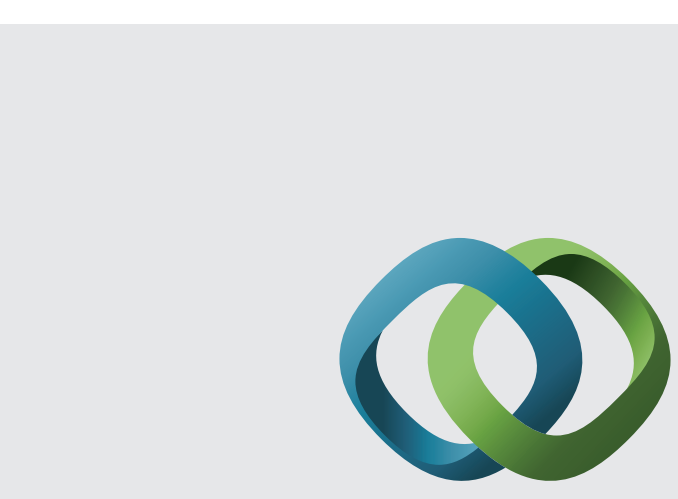

\section{Hindawi}

Submit your manuscripts at

http://www.hindawi.com
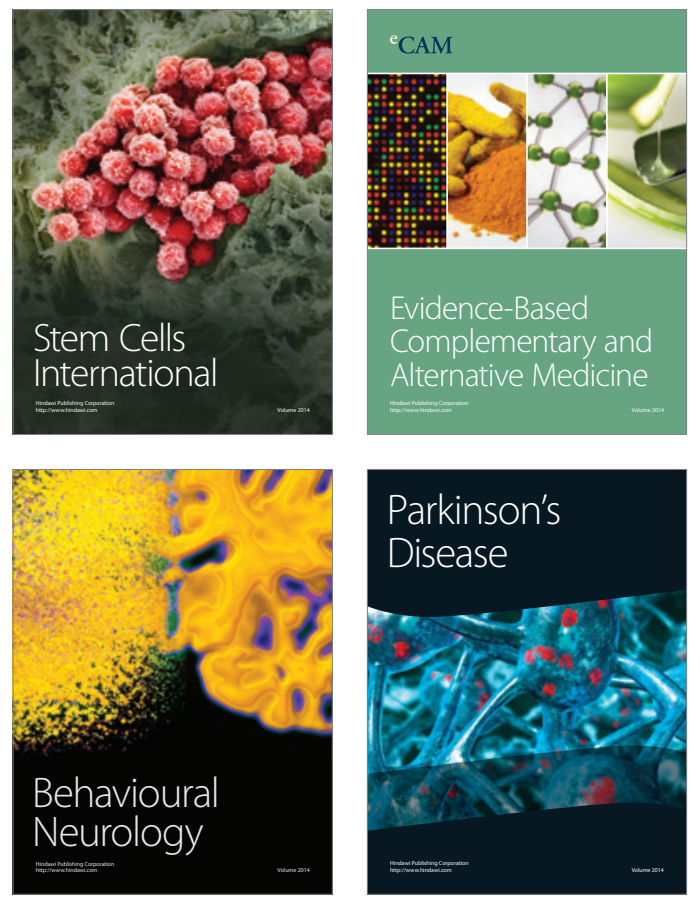
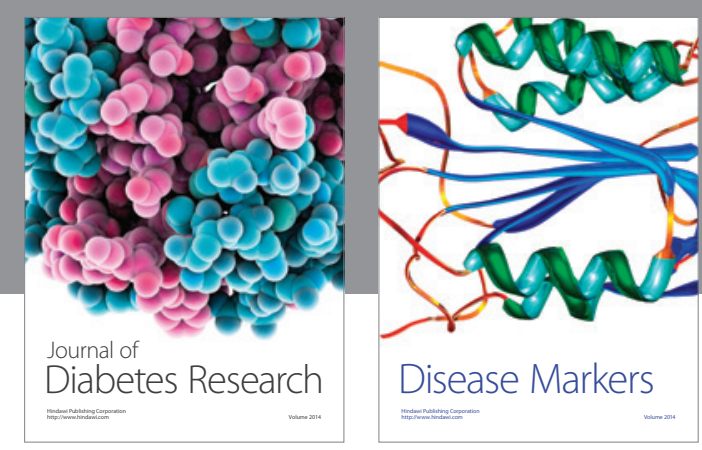

Disease Markers
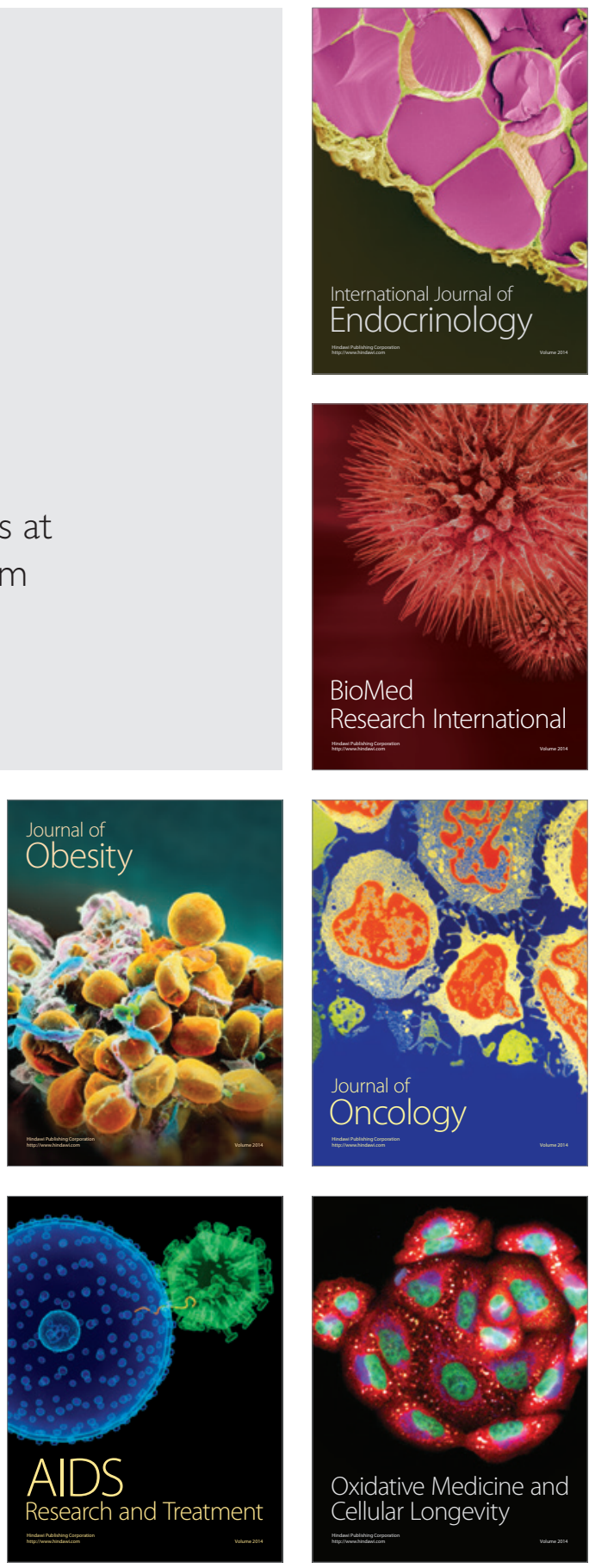